\title{
Resistant starch: Implications of dietary inclusion on gut health and growth in pigs: a review
}

\author{
Felina P. Y. Tan, Eduardo Beltranena and Ruurd T. Zijlstra* (D)
}

\begin{abstract}
Starch from cereal grains, pulse grains, and tubers is a major energy substrate in swine rations constituting up to 55\% of the diet. In pigs, starch digestion is initiated by salivary and then pancreatic a-amylase, and has as final step the digestion of disaccharides by the brush-border enzymes in the small intestine that produce monosaccharides (glucose) for absorption. Resistant starch (RS) is the proportion of starch that escapes the enzymatic digestion and absorption in the small intestine. The undigested starch reaches the distal small intestine and hindgut for microbial fermentation, which produces short-chain fatty acids (SCFA) for absorption. SCFA in turn, influence microbial ecology and gut health of pigs. These fermentative metabolites exert their benefits on gut health through promoting growth and proliferation of enterocytes, maintenance of intestinal integrity and thus immunity, and modulation of the microbial community in part by suppressing the growth of pathogenic bacteria while selectively enhancing beneficial microbes. Thus, RS has the potential to confer prebiotic effects and may contribute to the improvement of intestinal health in pigs during the post-weaning period. Despite these benefits to the well-being of pigs, RS has a contradictory effect due to lower energetic efficiency of fermented vs. digested starch absorption products. The varying amount and type of RS interact differently with the digestion process along the gastrointestinal tract affecting its energy efficiency and host physiological responses including feed intake, energy metabolism, and feed efficiency. Results of research indicate that the use of RS as prebiotic may improve gut health and thereby, reduce the incidence of post-weaning diarrhea (PWD) and associated mortality. This review summarizes our current knowledge on the effects of RS on microbial ecology, gut health and growth performance in pigs.
\end{abstract}

Keywords: Growth performance, Gut health, Resistant starch, Swine

\section{Background}

Nursery pig mortality is a complex interplay that involves the animal, and the environment, including diet and infectious etiologies [1]. In the United States, mortality rate of nursery pigs is $3.6 \%$ with enteric-related factors (failure to thrive, $22.1 \%$ and scours, 9.4\%) accounting for nearly one-third of nursery pig deaths (USDA, 2015). Post-weaning diarrhea is a multifactorial disease that occurs within 2 weeks after weaning and is

\footnotetext{
* Correspondence: ruurd.zijlstra@ualberta.ca

Department of Agricultural, Food and Nutritional Science, University of Alberta, Edmonton, AB T6G 2P5, Canada
}

most often characterized by diarrhea, dehydration, reduced growth performance, and mortality $[2,3]$. Although PWD can result in mortality of up to $25 \%$, the magnitude of mortality is often mild to moderate ranging from $1.5 \%$ to $2 \%[1,2]$. During the immediate postweaning period, various factors reducing feed intake have been identified and include dietary, microbiological, environmental factors and their interactions [4]. Refusal to eat and thus reduction in feed intake soon after weaning leads to morphological and functional changes in the intestine resulting in incomplete gut function, subsequent decrease in brush border enzyme activity, and

(c) The Author(s). 2021 Open Access This article is licensed under a Creative Commons Attribution 4.0 International License, which permits use, sharing, adaptation, distribution and reproduction in any medium or format, as long as you give appropriate credit to the original author(s) and the source, provide a link to the Creative Commons licence, and indicate if changes were made. The images or other third party material in this article are included in the article's Creative Commons licence, unless indicated otherwise in a credit line to the material. If material is not included in the article's Creative Commons licence and your intended use is not permitted by statutory regulation or exceeds the permitted use, you will need to obtain permission directly from the copyright holder. To view a copy of this licence, visit http://creativecommons.org/licenses/by/4.0/ The Creative Commons Public Domain Dedication waiver (http://creativecommons.org/publicdomain/zero/1.0/) applies to the data made available in this article, unless otherwise stated in a credit line to the data. 
thus absorptive capacity [4-6]. The various stressors and low feed intake compromise gut mucosal integrity causing increased intestinal pathogen permeability, translocation of bacteria, and subsequently inflammation [7]. These compromised digestive and absorptive functions contribute together with inflammation to PWD, dehydration and poor performance [8]. Dietary antibiotic growth promoters and therapeutic doses of zinc oxide and copper sulfate have been used over the last decades to prevent pathogenic diarrhea, maintain health and thus sustain growth performance of pigs. However, in recent years, concerns about antimicrobial resistance and the environmental impact of zinc oxide have prompted the swine industry to explore alternatives $[9,10]$. Adopting good animal husbandry practices including nutrition, feeding, management of the nursery environment, biosecurity, and disease prevention are indeed possible strategies to maintain gut health and pig performance without inclusion of dietary antibiotic growth promoters [11]. Diet formulation aspects to consider for optimum gut health include macronutrients (starch, protein, fiber, and fat) and minerals, antioxidant supplementation, and feed additives to modulate host immunity [8]. Specific dietary interventions such as reduction of protein content [12], inclusion of fermentable carbohydrates [13, 14] fiber, and resistant starch (RS) [15] can assist in the weaning transition from liquid milk to dry food. Specifically, RS may be regarded as prebiotic because most forms of RS have features such as stimulating beneficial gut bacteria, increasing total short-chain fatty acid (SCFA), more specifically butyrate levels that confer benefits to the host [16]. However to date, few studies in pigs have examined the efficacy of dietary RS on gut health in comparison with dietary antibiotics or in combination with prebiotics and probiotics [17]. The classification of RS and application of feed processing to alter the value of RS have been discussed in previous reviews [18-21]. The present review addresses the current state of knowledge on the effects of RS on gut health and resulting growth performance in pigs. Nursery and growing pig studies are the focus; some in vitro studies or in vivo studies using other monogastric animals (poultry and mice) as animal models are also cited.

\section{Resistant starch as prebiotic Starch chemistry}

Starch, the main carbohydrate in cereal and pulse grains, is stored in the amyloplast as discrete granules with distinct morphology in various botanical origins [22]. Starch consists primarily of $\alpha$-glucans in the form of amylose and amylopectin. Amylose is considered a linear polysaccharide composed of $\alpha$-D-glucose units with $\alpha$ 1,4-glycosidic linkages with less than $0.5 \% \alpha$-1,6-branching points [23, 24]. Amylopectin is a larger, more branched molecule comprised of $\alpha$-D-glucose units joined by $\alpha$-1,4-glycosidic bonds and $5 \%$ to $6 \% \alpha-1,6-$ glycosidic bonds $[25,26]$. Native starches from various botanical origins consist of $18 \%$ to $36 \%$ amylose and $72 \%$ to $82 \%$ amylopectin $[25,27,28]$. Starch is deposited as discrete granules in densely packed, concentric layers of growth rings containing alternating crystalline and amorphous regions [24]. Starch granules from a wide variety of plant sources display distinct crystalline structure and susceptibility to enzymatic and chemical reactions $[22,29,30]$. The crystallinity, granule size and surface area, ratio of amylose to amylopectin, porosity, structural inhomogeneities, and degree of integrity influence the susceptibility of the granules to the enzymatic action of $\alpha$-amylase [31-33]. Waxy starch granules, that are mostly amylopectin, are more readily hydrolyzed compared with granules with a greater content of amylose [34].

\section{Types of resistant starch}

The term resistant starch (RS) was first used to describe the portion of starch that was cooled in cooked foods but was resistant to digestion by $\alpha$-amylase [35]. This definition was then extended to include starch and its degradation subunits that reach the large intestine and there become substrate for microbial fermentation [36]. Resistant starch was later described as an analogous carbohydrate that should be considered as dietary fiber [27]. Resistant starch is classified based on the source, and physicochemical characteristics of starches [37]. The RS type 1 (RS1) are physically inaccessible starches in pulse grains and cereal grains (Table 1). Amylolytic enzymes are not able to reach these starches located within intact plant cell walls and unprocessed whole grains. The RS type 2 (RS2) are native resistant starch granules found in green banana and raw potato that are easily gelatinized with the presence of water at $60^{\circ} \mathrm{C}$ [37]. A second type of RS 2 (i.e. high amylose cornstarch) is characterized by its high resistance to gelatinization at temperatures above $120^{\circ} \mathrm{C}$ required for gelatinization $[58,59]$. The RS type 3 (RS3) are retrograded starches that occur when starchy food such as potato and bread are first cooked (gelatinized) and then recoil when cooled. The RS type 4 (RS4) are chemically modified starches that interfere with the action of amylases. For the latter, introduction of chemical bonds occurs through processes that include dextrinization, etherification, esterification, oxidation, and cross-linking utilizing chemical reagents $[58,59]$. The RS type 5 (RS5) is mainly associated to amylose-lipid V-type complexes such as starch-fatty acids and starch-monoglycerides that have reduced starch digestibility [60-62]. 
Table 1 Types of resistant starch (RS) and starch sources used in pig studies

\begin{tabular}{|c|c|c|c|}
\hline $\begin{array}{l}\text { Type of } \\
\text { RS }\end{array}$ & Description of RS & Starch sources used in pig studies & References \\
\hline \multirow[t]{2}{*}{$\mathrm{RS1}$} & \multirow[t]{2}{*}{$\begin{array}{l}\text { Native starch granules entrapped or inaccessible to } \\
\text { enzymes }\end{array}$} & $\begin{array}{l}\text { Hull-less barley, high moisture corn, low amylose barley and corn, oat, } \\
\text { rice, sorghum, triticale, wheat }\end{array}$ & {$[38]$} \\
\hline & & Field pea & [39] \\
\hline \multirow[t]{5}{*}{ RS2 } & \multirow{5}{*}{$\begin{array}{l}\text { Native starch granules with conformation or } \\
\text { structure that resist enzymes }\end{array}$} & Raw potato starch & {$[15,40-44]$} \\
\hline & & Sweet potato & [41] \\
\hline & & $\begin{array}{l}\text { Hull-less barley, high moisture corn, low amylose barley and corn, oat, } \\
\text { rice, sorghum, triticale, wheat }\end{array}$ & {$[38]$} \\
\hline & & Field pea & [39] \\
\hline & & High-amylose corn starch & [45-53] \\
\hline \multirow[t]{6}{*}{ RS3 } & \multirow{6}{*}{$\begin{array}{l}\text { Retrograded starch that occurs naturally during food } \\
\text { processing }\end{array}$} & Tapioca starch & {$[54,55]$} \\
\hline & & Barley & {$[38,39]$} \\
\hline & & Corn & {$[38]$} \\
\hline & & Field pea & {$[39]$} \\
\hline & & Rice & {$[38]$} \\
\hline & & Wheat & [38] \\
\hline RS4 & Chemically-modified starch & Enzymatically-modified starch & {$[56,57]$} \\
\hline
\end{tabular}

\section{Starch digestion vs. starch fermentation}

Starch digestion begins in the mouth and is initiated by salivary $\alpha$-amylase during chewing. Approximately $5 \%$ of starch is broken down by oral $\alpha$-amylase due to the short span of time in the mouth [63]. The acidic environment in the stomach restricts starch digestion to a minimum. The luminal phase of starch digestion continues in the small intestine with the secretion of pancreatic $\alpha$-amylase producing maltose, maltotriose, shortbranched oligosaccharides, and $\alpha$-limit dextrin. Further hydrolysis of disaccharides and oligosaccharides into monosaccharides by the brush border enzymes (maltaseglucoamylase and sucrase-isomaltase) occurs prior to absorption across the small intestinal epithelium [63, 64]. The final digestion product glucose is actively transported across the apical membrane of enterocytes via the $\mathrm{Na}^{+}$/glucose cotransporter 1 against an electrochemical gradient [65]. Less than $10 \%$ of glucose is absorbed passively via the paracellular route [66]. The limited studies found in pigs indicate that factors such as weaning age, feed intake, stressors, and diet composition may decrease passive absorption [67]. Glucose then exits the enterocytes at the basolateral membrane via a bidirectional, $\mathrm{Na}^{+}$-independent monosaccharide transporter, glucose transporter 2 . The $\mathrm{Na}^{+} /$glucose cotransporter 1 is the major route for the transport of glucose from the lumen into enterocytes. However, based on studies in rats and cell lines, increasing evidence indicates that glucose transporter 2 can be rapidly recruited to the brushborder membrane when the luminal glucose concentration is high and thereby, increases the capacity of glucose uptake by the enterocytes [68-71]. Starch digestion is influenced by the ratio amylose: amylopectin and branch chain-length distribution of amylopectin [59]. Indeed, starch with high amylose content reduced the rate of starch digestion and thus lowered postprandial blood glucose compared with starch with lower amylose content [49]. The crystalline structure and amylopectin chain length in starches of different botanical origin strongly influenced the rate of starch digestion in an in vitro model mimicking porcine digestion [52].

A proportion of starch resists enzymatic degradation in the small intestine and so passes into the large intestine (resistant starch) to be fermented by the resident microbiota to produce SCFA, $\mathrm{CO}_{2}, \mathrm{H}_{2}$, and $\mathrm{CH}_{4}$ [72]. The SCFA produced are rapidly absorbed from the lumen either by passive diffusion or active transport utilizing monocarboxylate transporter 1 (MCT1) or $\mathrm{Na}^{+}$dependent monocarboxylate transporter 1 [73]. Oxidation of SCFA contributes approximately $60 \%$ to $70 \%$ of energy to colonocytes with butyrate as the main energy source, whereas the remaining SCFA are transported across the basolateral membrane by MCT4 [73]. Lesser known MCT isoforms (MCT2 and MCT4) are found in the small intestine and colon of the pig [74].

The most commonly used techniques to assess digestion of starch in pigs are ileal cannulation, portal-vein catheterization, and slaughter techniques [75]. In ilealcannulated pigs, the insertion of a cannula at the terminal ileum allows for the collection of digesta and feces. Apart from measurements of nutrient digestibility, bacteria and metabolites can be quantified from these samples [76]. The use of indigestible markers such as chromic oxide, allows for the quantification of the extent 
of starch digestion in the small vs. large intestine. In portal-vein catheterization, pigs are surgically fitted with indwelling catheters in the portal vein and carotid artery, and a flow probe is installed around the portal vein [77]. With this technique, the kinetics of starch digestion and absorption of metabolites such as glucose, lactic acid, short-chain fatty acids, and amino acids can be studied [75]. Alternatively, p-aminohippuric acid can be administered into the bloodstream to measure portal blood flow and nutrient fluxes [78]. The slaughter technique involves euthanizing pigs at a specific time point after meal and followed by prompt collection of digesta samples and sometimes tissue at multiple sites of the gastrointestinal tract [79]. This technique provides a localized progression of starch digestion without surgery, thereby, minimizing the risk of altering gut physiology [75] but is a static portrait of digestion at sampling sites rather than a reflection of the dynamics of the digestion process over time as influenced by peristalsis and nutrient flow.

\section{Interaction with other feed components}

In cereal and pulse grains, several non-starch components that are associated with the starch granules may restrict the digestibility of starch. In vitro studies have indicated that amylose-lipid complexes reduced the accessibility of $\alpha$-amylase to amylose for digestion [80]. The rate of $\alpha$-amylolysis is also affected by the proteinstarch structural network that forms in the seed endosperm, many of which are hydrophobic [81, 82]. Starch and phenolic compounds such as tannins, phenolic acids, flavonoids, and lignans also interact through hydrophobic and hydrogen bonds to inhibit gastrointestinal enzyme activity to different extents depending on the type of phenolic compounds and type of starch [83, 84]. Non-starch polysaccharides such as mixed-linked $\beta$ glucans present in some cereals such as barley and oat grain encapsulate both protein and starch, thereby, decreasing enzyme accessibility, reducing starch digestion and the rate of postprandial glycemia $[85,86]$.

\section{Effect of resistant starch on gut health}

\section{Gut microbial profile and diversity}

In pigs, the estimated size of the microbial population is approximately $10^{10}$ to $10^{11}$ per gram of gut content [8789]. The largest proportion of bacteria in the pig intestinal microbiome is from the phyla Firmicutes, followed in descending order by Bacteroidetes, Proteobacteria, Actinobacteria, and Spirochaetes [90, 91]. Firmicutes and Bacteroidetes constitute $90 \%$ of the microbiota with Prevotella from Bacteroidetes phyla being the predominant genus [91, 92]. In the ileal digesta of pigs, the major phylas are Firmicutes and Proteobacteria, with facultative anaerobes Lactobacillus and Enterobacteriaceae being the most dominant $[92,93]$. The phyla Firmicutes,
Bacteroidetes, and Proteobacteria comprise together $90 \%$ of the microbiota in pigs at 7-day post-weaning and 84\% at 27-day post-weaning. In both post-weaning age groups, Lactobacillus was the predominant genus (46\%58\%), followed by Prevotella (16\%-30\%) in both the jejunum and colon [92]. As post-weaning age increases, the relative abundance of Proteobacteria phyla decreases. This phylum consists of many pathogenic, gram negative bacteria such as Escherichia, Salmonella, Vibrio, Helicobacter, and Campylobacter, all of which are often negatively associated with gut health [90, 91]. Enterotoxigenic E. coli proliferation is widely known as a main cause of PWD [94]. Recent findings of high abundance of Campylobacter in 7-day post-weaning piglets with diarrhea indicates that these bacteria may also play a relevant role in PWD [92].

The composition and activity of microbes is largely influenced by diet, especially dietary carbohydrates [9597]. Genes coding for enzymes involved in starch, $\beta$ glucan, xylose, and arabinose digestion were particularly enriched in fecal samples from weaned pigs [97]. Metagenomic analyses revealed that Firmicutes possess the extracellular $\alpha-(1,4)$-glucan branching enzyme and Bacteroidetes possess the periplasmic neopullulanase and $\alpha$ glucosidase enzymes for starch fermentation in the hindgut [98]. Diets containing purified native starches with amylose ranging from 0 to $80 \%$ of starch did not affect the microbial diversity in the large intestine of grower pigs; however, high amylose corn starch (80\%) selectively promoted the incidence of Bifidobacterium spp. in feces (Table 2) [93]. In weaned pigs, increasing amylose from 0 to $63 \%$, increased Bifidobacterium spp. but decreased Clostridia clusters IV and XIVa in cecal and colonic digesta [51]. Previously, high amylose corn starch (85\%) increased lactobacilli population in the hindgut of weaned pigs [47]. A meta-analysis of 24 research articles indicated that increasing RS type 2 starch with a minimal dietary content of $10 \%$ of this in pigs, reduced $\mathrm{pH}$ and promoted lactobacilli and bifidobacteria in the feces; thus, potentially limiting the growth of pathogenic bacteria in the hindgut [99] (Fig. 1). In one study, feeding weaned pigs $14 \%$ of raw potato starch (RPS) reduced the richness and diversity of the microbial species in the colon [15]. Consumption of a RS type 3 starch diet lowered Firmicutes:Bacteroidetes ratio in digesta of the proximal colon in pigs, increased abundance of butyrateproducing Faecalibacterium prausnitzii, and decreased pathogenic members of Gammaproteobacteria such as Escherichia coli [54]. In pigs, differences observed in cecal and colonic microbiota are likely due to the alteration in the chemical structure of resistant starch at different intestinal sites [54]. The changes in microbial profile with the alteration of dietary starch content and structure supports the concept that the amount and rate 
Table 2 Microbial effects of resistant starch (RS) in pig studies

\begin{tabular}{|c|c|c|c|}
\hline Test animals $^{\mathrm{a}}$ & Types of RS & Microbial effects $^{b}$ & References \\
\hline Nursery pigs & RPS (RS 14\%) & Increased colonic lactobacilli and Bacteroides & [15] \\
\hline Nursery pigs & $\begin{array}{l}\text { Purified corn starch }(63 \% \\
\text { amylose) }\end{array}$ & $\begin{array}{l}\text { Increased cecal and colonic Bifidobacterium } \\
\text { Decreased Clostridium clusters IV and XIVa }\end{array}$ & [51] \\
\hline Nursery pigs & $\begin{array}{l}\text { High amylose corn starch (85\% } \\
\text { amylose) }\end{array}$ & Increased proximal colonic Lactobacilli and Bifidobacteria & [47] \\
\hline Growing pigs & $\begin{array}{l}\text { RS2 in corn, potato, barley, pea, } \\
\text { tapioca }\end{array}$ & Increased fecal lactobacilli and bifidobacteria (meta-analysis) & [99] \\
\hline Growing pigs & $\begin{array}{l}\text { High amylose corn and RPS (RS } \\
11 \%)\end{array}$ & No significant changes in microbial composition & [42] \\
\hline Growing pigs & $\begin{array}{l}\text { Retrograded tapioca starch (RS } \\
34 \%)\end{array}$ & $\begin{array}{l}\text { Increased colonic Ruminococcus bromii, and bacterial group Clostridium cluster } \\
I V, I X, X V, X V I \text {, and XVII } \\
\text { Decreased colonic Gammaproteobacteria }\end{array}$ & [54] \\
\hline Growing pigs & $\begin{array}{l}\text { Retrograded tapioca starch (RS } \\
33 \%)\end{array}$ & Increased Lachnospiraceae- and Ruminococcus-affiliated phylotypes & [55] \\
\hline $\begin{array}{l}\text { Cannulated growing } \\
\text { pigs }\end{array}$ & $\begin{array}{l}\text { Purified corn starch (63\% } \\
\text { amylose) }\end{array}$ & Increased fecal Bifidobacterium & [93] \\
\hline $\begin{array}{l}\text { Growing-finishing } \\
\text { pigs }\end{array}$ & Purified RPS (RS 13 to $15 \%$ ) & $\begin{array}{l}\text { Increased Coprococcus, Ruminococcus, and Turicibacter } \\
\text { Decreased Sarcina and Clostridium }\end{array}$ & [43] \\
\hline $\begin{array}{l}\text { Gestating and } \\
\text { lactating sows }\end{array}$ & Pea starch (RS 5 to $9 \%$ ) & Increased Bifidobacterium and ratio of Firmicutes to Bacteroidetes & [100] \\
\hline Pregnant sows & RPS (RS 5\%) & Increased fecal Clostridia & [82] \\
\hline
\end{tabular}

${ }^{\mathrm{a}} \mathrm{BW}$ of pigs at the start of the study: nursery pigs, 6 to $27 \mathrm{~kg}$; growing pigs, 30 to $63 \mathrm{~kg}$; finishing pigs, $70 \mathrm{~kg}$ and above.

${ }^{\mathrm{b}}$ Microbial composition represented by relative abundance.

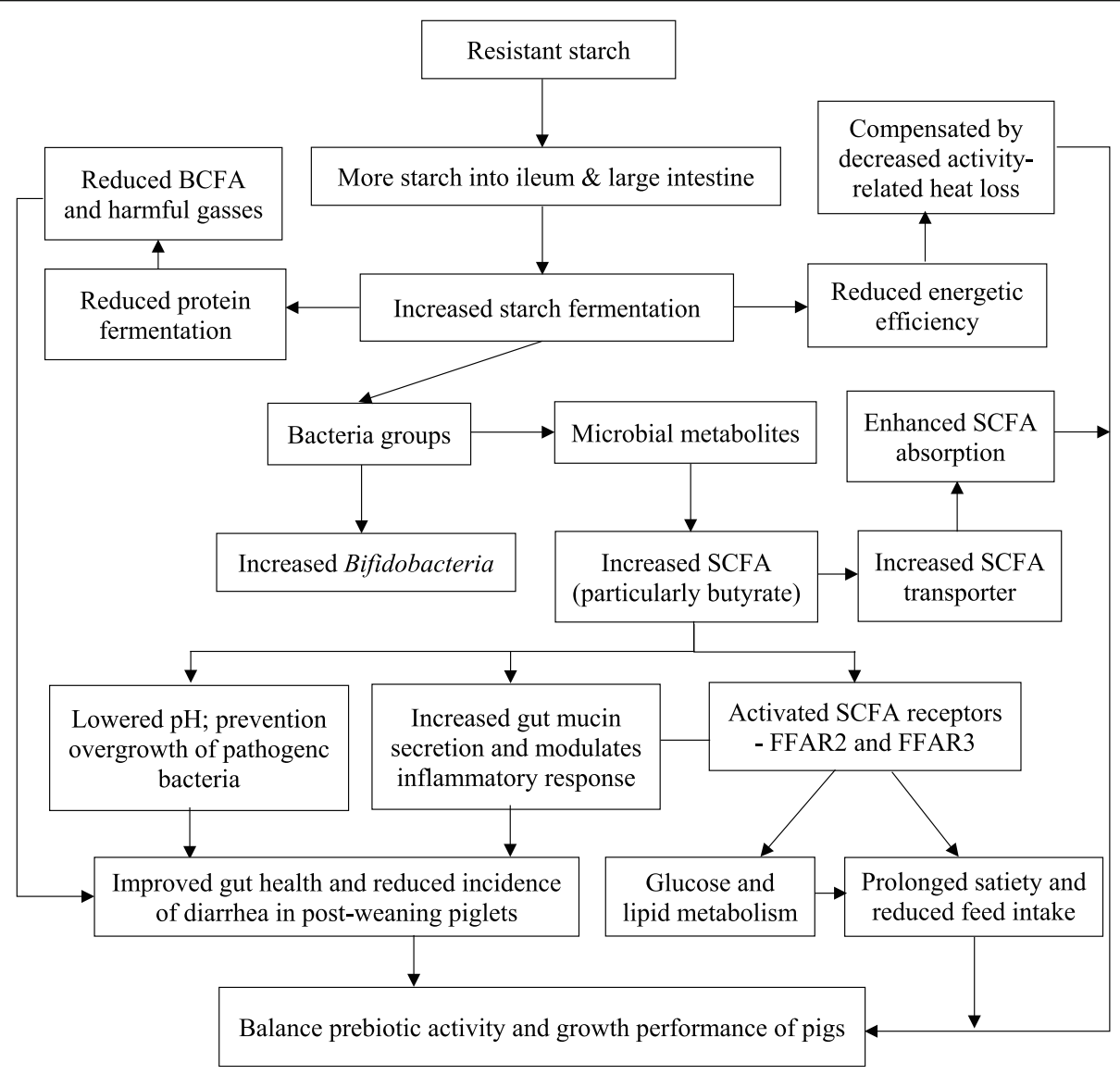

Fig. 1 Schematic illustration of the effects of resistant starch on gut health and growth in pigs 
of starch that is available for fermentation in the distal region of the gut selectively increased the beneficial bacteria in the gut [101]. Finally, evidence was provided recently for a link between porcine gut microbiota and growth and feed efficiency. Certain bacterial taxa (e.g., Treponema, Methanobrevibacter, and Lactobacillus) that are involved in nutrition digestion, energy harvest, and anti-inflammatory effects are indeed consistently associated with improvements in productivity [102].

\section{Gut microbial mediators}

Plant cell wall polysaccharides, oligosaccharides, and resistant starches that are not digested by endogenous enzymes in the small intestine are degraded by microbial polysaccharidases and glycosidases to monomers such as glucose, which are then fermented to produce SCFA (mainly acetate, propionate, and butyrate) and gases $\mathrm{CO}_{2}, \mathrm{H}_{2}$, and $\mathrm{CH}_{4}$ [103]. Acetate is mainly taken up by the liver to be used as an energy source and as precursor for the synthesis of fatty acids and cholesterol. Propionate is used mainly as a precursor for gluconeogenesis in the liver, kidney, muscle and intestine. Butyrate is the preferred energy source for colonocytes, whereas the remainder SCFA are oxidized by hepatocytes [104, 105]. Minor fermentation products such as ethanol, lactate, and succinate are intermediate products that are metabolized through cross-feeding interactions between bacterial species in the large intestine [106].

The greatest microbial activity occurs in the cecum and proximal colon of the pigs; however, substantial microbial activity also takes place in the distal section of the small intestine $[42,107,108]$. The amount and type of substrate (typically fermentable carbohydrate) affects the microbiota population, thereby, the type and amount of SCFA produced [73, 103, 109]. Actual intestinal SCFA production, however, is not reflected by SCFA concentration in the gut because SCFA are rapidly absorbed (> 95\%) from the gut lumen and metabolized by the host $[105,107]$.

Across pig studies, diets high in RS or amylose increased intestinal SCFA concentrations. Slowly digestible starch (63\% amylose) increased ileal starch and total butyrate content [49], and SCFA concentration in the cecum and feces [51]. Both RS type 2 and RS type 3 starch also increased cecal and fecal SCFA [44, 54]. The increase in butyrate production has been positively associated to the increased in SCFA transporter, MCT1 mRNA abundance in some pig studies [54, 110].

At weaning, refusal to eat or drastic reduction in feed intake decreased villus height and increased crypt depth, thus reducing brush-border enzyme activities and nutrient digestion [111, 112]. Other than carbohydrates, undigested protein is also expected to reach the hindgut to a greater extent during the post-weaning period. This undigested protein, along with protein of endogenous origin, is available for fermentation by bacteria resulting in greater protein catabolic activity, and increased formation of SCFA, branched-chain fatty acids (mainly isobutyrate, isovalerate, and 2-methylbutyrate), and gasses such as ammonia, phenols, indoles, and amines that are potentially harmful [109] (Fig. 1). The major amino acidfermenting bacteria in the gut of pigs are members of Proteobacteria (E. coli, Klebsiella spp.), Firmicutes (Streptococcus spp., Clostridium bifermentans, Clostridium difficile, Clostridium perfringens, Megasphaera elsdenii, and Acidaminococcus fermentans), Bacteroidetes [113]. Protein fermentation is not limited to only the hindgut but may happen to a lesser extent in the distal small intestine. Some of the bacteria that have been specifically identified in the small intestine of pigs include Escherichia coli, Klebsiella spp., Streptococcus spp., Megasphaera spp., and Acidaminococcus fermentans [114]. Akkermansia muciniphila, a mucin-degrading bacteria, contributed substantially to nitrogen cycling in the small intestine [115]. Previous studies have indicated that synthesis of bacterial protein primarily occurs in the distal small intestine whereas bacterial protein catabolism mostly occurs in the large intestine. This rate of bacterial protein synthesis and degradations seems to depend on the availability of fermentable carbohydrates $[114,116,117]$. Increasing dietary fermentable carbohydrates shifted nitrogen excretion from urine to feces, thus reducing potentially harmful protein metabolites such as ammonia [118].

\section{Gut pH}

The interaction between diet, intestinal environment and gut bacteria is complex: fermentation of RS leads to increased production of SCFA, which lowers gut $\mathrm{pH}$, thereby affecting microbial composition and in turn, affects both the type and production rate of SCFA [73] (Fig. 1). High amylose starch increased intraluminal SCFA concentrations and lowers $\mathrm{pH}$ in digesta and feces of pigs $[47,51]$. Greater SCFA concentration from ileum to cecum lowers this gut section $\mathrm{pH}$ and therefore prevents overgrowth of pathogenic Enterobacteriaceae and Clostridia [119, 120]. As fermentable substrates progressively deplete in the distal part of the large intestine, SCFA concentration declines along from the cecum to the distal colon, and $\mathrm{pH}$ increased from 5.6 to 6.6 [121]. The increased $\mathrm{pH}$ caused a microbial shift from butyrate-producing bacteria such as Roseburia spp. and Faecalibacterium prausnitzii to acetate- and propionate-producing bacteria (mainly Bacteroides) [122, 123]. 


\section{Gut immune response}

In pigs, important gastrointestinal development occurs in the first three months after birth $[124,125]$. The establishment of the epithelial barrier coincides with the development of the enteric nervous system and maturation of the adaptive and innate immune system [124, 125]. In commercial pig production, pigs are generally weaned between 14 to 30 days. Other stressors associated with weaning (such as maternal separation, establishment of social hierarchy, disease, and environmental challenges) occurs during the critical period of gastrointestinal barrier development, thereby, affecting the immune maturation processes in the intestinal tract [124]. The effects of weaning on gastrointestinal health are well documented; however, the underlying mechanisms are not fully understood. Weaning stress in pigs has been proposed to trigger corticotropin-releasing factor leading to mast cells activation and release of mast cell mediators such as proteases and tumor necrosis factor (TNF-

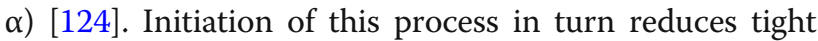
junctions and increases intestinal permeability allowing the translocation of bacteria and microbial products [124-126]. Several animal studies demonstrated that stress due to weaning induced impaired intestinal barrier function, reduced mRNA expression of tight junction proteins (occludin, claudin-1, and zonula occludens-1) and upregulated expression of pro-inflammatory cytokines (TNF- $\alpha$ and interleukin (IL)-6; Table 3).

In addition to the potential to alter the diversity and stability of gut microbiota, RS affects the intestinal expression of genes involved in immune regulation and thereby gut health. Among SCFA, especially butyrate produced by RS fermentation serves as the primary energy source for the colonocytes, and regarded as the modulator of intestinal barrier function and immunity [131, 132]. Recently, finishing pigs with Prevotella-rich enterotype that were fed a diet containing high amylose (68\% amylose) corn starch had decreased gene expression of inflammatory cytokines in the colonic mucosa [129]. Feeding a diet containing 34\% RS suppressed genes (Table 3) that are involved in many of the immune response pathways in adaptive and innate immune system [113]. In multiple studies, mainly in cell lines and mice, the potential of SCFA in regulating T-cell metabolism and controlling gut inflammatory responses was established [133-137]. Butyrate suppressed proinflammatory cytokine production, therefore, suppression of immune response in a high RS diet is likely due to increased SCFA concentration [138, 139]. Long-term intake of RS may affect the immune response. Pigs fed sequentially a diet containing 23\% RPS during the growing phase and 28\% RPS during the finishing phase, increased expression of colonic mucin genes (MUC4, $M U C 5 A C$, and $M U C 12$ ) compared with feeding a corn starch diet. Therefore, long-term intake of RS may consequentially improve gut health by increasing mucin secretion and lowering the incidence of bacterial products translocation across the gut barrier [128, 140]. Using transcriptomic analysis, pigs that were fed a diet containing $13.3 \%-15.4 \%$ of RS for 100 days altered colonic expression of genes involved in immune response; however, expression of the pro-inflammatory cytokine gene IL- $1 \beta$ also increased. Hence, long-term intake of RS may exert both positive and negative effects on gut

Table $\mathbf{3}$ Immunomodulatory effects of resistant starch (RS) in animal studies ${ }^{a}$

\begin{tabular}{|c|c|c|c|}
\hline $\begin{array}{l}\text { Test } \\
\text { animal }\end{array}$ & Type of RS & Immune effects & References \\
\hline $\begin{array}{l}\text { Grower } \\
\text { pigs }\end{array}$ & High amylose corn and RPS (RS 11\%) & Increased TNF-a, MCP2, MUC2 & [110] \\
\hline $\begin{array}{l}\text { Grower } \\
\text { pigs }\end{array}$ & Retrograded tapioca starch (RS 34\%) & $\begin{array}{l}\text { Increased PPARY } \\
\text { Decreased NFKB, TLR4, BCL6, ICOS, and CR2 }\end{array}$ & [127] \\
\hline $\begin{array}{l}\text { Grower } \\
\text { pigs }\end{array}$ & RPS (RS > 13\%) & $\begin{array}{l}\text { Increased IL-1 } \beta \text {, F7, PollII, TLR6 } \\
\text { Decreased CD4, ITGB3, CTSB, C1S, SERPING1, TLR7 }\end{array}$ & [43] \\
\hline $\begin{array}{l}\text { Grower } \\
\text { pigs }\end{array}$ & RPS (RS 15.3\%) & Increased MUC4, MUC5AC, and MUC12 & [128] \\
\hline $\begin{array}{l}\text { Finishing } \\
\text { pigs }\end{array}$ & $\begin{array}{l}\text { High amylose corn starch (68.5\% } \\
\text { amylose) }\end{array}$ & Increased IL-6, IL-12, IL-1 $\beta$, and TNF-a in pigs with Prevotella-rich enterotype & [129] \\
\hline $\begin{array}{l}\text { Pregnant } \\
\text { sows }\end{array}$ & $\begin{array}{l}\text { Pea starch (Gestation RS 5.4\%; } \\
\text { Lactation RS 8.6\%) }\end{array}$ & Increased zonula occludens-1 in piglets & [100] \\
\hline $\begin{array}{l}\text { Pregnant } \\
\text { sows }\end{array}$ & RPS (RS $5 \%)$ & Increased MUC2, IL6, DEF1B, cecal immunoglobulin A, and regulatory $T$ cells & [44] \\
\hline Ducks & RPS (RS 3.8\%, 7.4\% and 19.5\%) & $\begin{array}{l}\text { Increased claudin-1, zonula occludens-1, MUC2, reduced plasma TNF- } \alpha \text {, IL-1 } \beta \text { and } \\
\text { endotoxin (RS 7.4\%) }\end{array}$ & [130] \\
\hline
\end{tabular}

${ }^{a} B C L 6$ B-cell lymphoma 6, CD4 Cluster of differentiation 4, CR2 Complement receptor type 2, CTSB Cathepsin B, C1S Complement component 1S, DEF1B Defensin beta 1, ICOS Inducible T cell co-stimulator, IL Interleukin, ITGB3 Integrin subunit beta 3, MCP2 Monocyte chemoattractant protein 2, MUC Mucin, NFKB Nuclear factor kappa B, PollII RNA polymerase III, PPARY Peroxisome proliferator-activated receptor, RPS Raw potato starch, SERPING1 Serpin Family G Member 1, TLR Toll like receptor, TNF- $a$ Tumor necrosis factor alpha 
health [43]. Pro-inflammatory cytokine signaling has also been linked to increased protein fermentation and down-regulation of MCT1 in the colon of pigs [141].

\section{Effect of resistant starch on energy metabolism and growth performance \\ Metabolic responses}

Apparent total tract digestibility of starch is mostly complete; however, apparent ileal digestibility of starch differs depending on its botanical origin [142, 143]. Feeding pigs a slowly digestible starch such as yellow field pea starch (67\% inclusion) and RPS (32.5\% to 65\%) decreased net portal flux of glucose but simultaneously increased net portal flux of SCFA [144, 145]. As established, diets high in RS (high amylose) can increase substrate flow into the hindgut thereby promoting microbial fermentation evidenced by increased total SCFA concentration [47, 51, 93]. Pigs fed diets containing high amylose corn starch [93], raw potato starch [145], and slowly degradable yellow field pea starch [144] have decreased glucose absorption. These findings indicate that in pigs fed a diet containing slowly digestible purified starch of corn, raw potato, or field pea, the intestinal wall metabolizes more glucose, or a portion of dietary starch is fermented in the small intestine. Thus, digestibility of starch alone does not explain the rate of glucose absorption. Previously, in vitro starch digestion was used to accurately predict the kinetics of net portal vein appearance of glucose in pigs by applying the corrections for gastric emptying and intestinal glucose utilization [146].

Resistant starches affect host glucose and lipid metabolism by altering the profile of metabolites in systemic circulation such as glucose, cholesterols, triglycerides, and SCFA. Pigs fed diets containing a wide range of amylose or RS have a reduction in postprandial glucose and insulin responses, hence, indicating that a specific starch characteristic may not entirely explain the starch effect on postprandial glucose. In portal veincatheterized pigs, the net portal appearance of glucose, insulin, C-peptide, and glucose-dependent insulinotropic polypeptide was lowered in pigs fed slowly digestible starch [93]. Insulin secretion peaked prior to peak glucose absorption when pigs were fed a rapidly digestible starch. The presence of glucose in the intestinal lumen facilitates incretin secretion, which accounts for $50 \%$ to $70 \%$ of the insulin secreted [147]. Two incretins hormones that are important for metabolism of starch metabolites are a) glucose-dependent insulinotropic polypeptide that is secreted from $\mathrm{K}$ cells predominantly located in the duodenum, and b) proximal jejunum and glucagon-like peptide-1 (GLP-1) secreted from L cells at the distal small intestine and colon $[148,149]$. The other likely reason is the presence of intestinal glucose sensor(s), taste receptor type 1 family (T1R2 + T1R3) in the lumen of the intestine in the presence of free digesta glucose [150, 151].

In mammalian species, evidence is accumulating that SCFA production directly affects pancreatic secretion of insulin [152]. The SCFA may act as signaling molecules by activating its receptors, G-protein coupled receptors 43 (FFAR2), and G-protein coupled receptors 41 (FFAR3) that triggers cell-specific signaling cascades [153]. These receptors are expressed in the ileum, colon, and insulinsensitive tissues such as adipose tissue, skeletal muscle, liver, and pancreas, thereby, the potential involvement in regulation of glucose and lipid metabolism [73]. Activation of FFAR2 and FFAR3 stimulates the secretion of the incretins GLP-1 and peptide YY (PYY) [154-156]. The PYY, a satiety-related hormone produced by the L-cells in the colon, reinforces the action of insulin by increasing glycemic control in rats [157-159]. In rats, increased FFAR2 was associated with increased GLP-1 in the proximal colon [160]. Furthermore, butyrate had a slower potency than acetate and propionate in stimulating GLP-1 secretion in the basolateral membrane of the colonic cells [161]. In pigs fed a diet with high RS (34\%), expression of FFAR2 and FFAR3 did not differ; however, the possibility that receptors were activated is not excluded [162]. Production of SCFA does not seem related to expression of proglucagon, but increased net portal SCFA from fermentation of RS increasing net portal GLP-1 and decreasing glucose-dependent insulinotropic polypeptide in pigs [49].

An earlier study in humans identified that dietary inclusion of 5.4\% RS (high amylose corn starch) increased fermentation products, SCFA, and fat oxidation, and thereby may decrease fat accumulation in the long term [163]. In pigs, glucose and insulin are potent signals that upregulates the expression of lipogenic enzymes [164, 165]. In weaned pigs, starch with faster digestion rate (68.9\% total starch; 3.5\% amylose and 96.5\% amylopectin) produced more postprandial blood glucose, insulin, and circulating lipids (triglyceride, total cholesterol, lowdensity lipoprotein cholesterol, and high density lipoprotein cholesterol) [166]. In addition, the expression of primary lipogenic enzymes, fatty acid synthase, acetyl CoAcarboxylase, and ATP-citrate lyase in the liver and adipose tissue, were increased in pig fed highly digestible starch [166]. Indeed, weaned pigs fed cassava starch containing $80 \%$ amylopectin had a greater insulinemic response than pigs fed corn starch containing 70\% amylopectin and stimulated lipogenesis in the liver [167]. Recently, oral administration of SCFA to growing pigs prevented fat deposition [168]. More specifically, acetate downregulated expression of genes involved in de novo synthesis of fatty acids; fatty acid synthase, acetyl CoA-carboxylase, and sterol regulatory element binding protein 1c (SREBP-1C), whereas butyrate enhanced expression of genes involved in fatty acid 
oxidation; hormone-sensitive lipase and carnitine palmitoyltransferase 1 . In finishing pigs, pea starch with high amylose content $(51.1 \%$ total starch; $28 \%$ amylose and $72 \%$ amylopectin) consistently induced downregulation of lipogenesis [169].

\section{Whole body energy metabolism}

Previously, RS that is fermented to SCFA was shown to be approximately $17 \%$ less efficient than starch that are digested and absorbed as glucose from the small intestine [170]. In the net energy system, energy efficiency from fermented starch is $70 \%$ compared with in-vitro enzymatically-degradable starch [171]. Using indirect calorimetry, the net energy value of fermented RS (retrograded corn starch) was $83 \%$ of the net energy value of enzymatically degradable starch [172]. The differences in energetic efficiency raises the question if switching from digested starch to fermentable starch reduces growth and feed efficiency. Most starch sources (both RS and digested starch) are almost completely degraded in the gastrointestinal tract reaching $100 \%$ apparent total tract digestibility; however, apparent ileal digestibility of these starch sources varies: cereal grains (84.8\% to 99.4\%), pulse grains ( $78 \%$ to $91 \%)$, purified starches $(69.7 \%$ to $97.5 \%$ ), and tuber (78\% to $91 \%$ ) [173]. The equation that predicts net energy value recommended in North America utilizes total starch as analyzed without considering its actual energetic efficiency [174, 175]. However using total analyzed starch in the equation is a major limitation because, as per the foregoing discussion, starch digestion and starch fermentation cannot be physiologically unlinked. Indeed, differences in site, extent or kinetics of starch digestion affect the energetic efficiency of digested vs. fermented starch due to changes in absorption and subsequent metabolism that affect energy loss through heat production [49, 147, 173]. Part of the lower energetic efficiency of RS due to increased heat increment may be compensated by reducing energy losses due to activity-related heat production that varies between $5 \%$ to $35 \%$ of maintenance heat production [176-179] (Fig. 1).

\section{Feed intake and growth}

Feed intake regulation likely involves two processes: (1) rate of passage of digesta or transit time [180] and (2) activation of the brain satiety and hunger center as a result of feed consumption, digestion, and metabolites production [180, 181]. The rate of macronutrient digestion that determines the site of digestion and also feed intake control through modification of satiety provide opportunities to improve feed efficiency [182]. Currently, some evidence exists that RS can decrease appetite and short-term food intake; however, the underlying mechanisms are not clearly understood, and findings have been inconsistent. Potential mechanisms include first, SCFA produced by hindgut fermentation stabilize postprandial glucose preventing a decline below basal glucose levels thereby prolonging satiety [183]. Second, luminary SCFA stimulate the release of incretins GLP-1 and PYY that promote satiety via a neural inhibitory effect in the brain $[73,182,184]$. Slow digestion of starch towards the end of the small intestine activates an ileal physicochemical brake switch causing delayed gastric emptying and thus, stimulating the satiety center in the brain via hormonal and neural signals [185]. The SCFA may also activate FFAR2 to release serotonin in the colon, thereby contributing further to satiety [184]. Recently, oral administration of acetate in growing pigs had the greatest effects on appetite suppression via enhanced leptin, PYY and GLP-1 secretions [168]. Although current available evidence to support SCFA role in appetite regulation are mainly from animal models such as rats, targeting these mechanisms may be a potential strategy to improve appetite regulation through dietary intervention [186].

Findings on satiety-related effects of RS or SCFA in pigs are rather limited and inconsistent. Rapidly digestible starch stimulated insulin release that consequently inhibited feed intake and increased adiposity [187]. In contrast, slowly digestible starch facilitated protein accretion resulting in leaner and faster growing pigs [187]. Growth performance and feed intake, were reduced in weaned pigs fed slowly digestible starch containing $63 \%$ amylose [51] or a diet with $20 \%$ RS [188]. In contrast, results from another study showed that 7\% of RPS reduced post weaning diarrhea in weaned piglets without affecting growth performance [15]. In other studies, growth performance of weaned [167] and finishing pigs [189] was unaffected by dietary inclusion of $30 \%$ amylose, indicating that such variations may exist due to the different RS sources and amounts consumed [190]. Incremental intake of $40 \%$ rapidly digestible starch increased fat deposition but did not affect feed efficiency when compared with feeding $40 \%$ slowly digestible starch [166]. In a study with pigs having ad-libitum access to feed, 30\% greater RS intake did not affect feed intake pattern and growth rate of pigs likely because microbial-produced SCFA were absorbed and available as energy source thereby sparing glucose from oxidation [191]. In grower pigs, feeding diets containing 34\% RS showed induced behavioral signs of increased satiety despite lack of increased plasma GLP-1 and PYY concentrations. The satiety effects observed were likely because of increased SCFA production and decreased postprandial glucose concentration and thus insulin response [192]. Separately, increased PYY secretion in response to RS supplementation is not caused by increased SCFA but rather by increased flow of intestinal digesta and neural reflexes [193]. Overall, results of the reviewed experiments 
indicate that dietary inclusion of up to $30 \%$ RS did not affect growth performance in growing or finishing pigs. However, dietary inclusion of RS above $30 \%$ may reduce feed intake in growing pigs. In addition, the mixed results observed for weaned pigs indicate that the overall outcome of dietary RS inclusion may also depend on starch source or the age of pigs. Combined, dietary inclusion of RS may regulate satiety and reduce feed intake in pigs without affecting growth performance, thus, improving feed efficiency.

\section{Conclusions}

Resistant starch is the proportion of starch that escapes small intestine digestion producing mostly glucose but instead undergoes microbial fermentation in the distal small intestine and colon producing SCFA. Results of in vitro and in vivo studies support the view that RS acts as prebiotic to modulate gut microbiota by changing the intestinal microbial composition and function. In addition, specific bacteria phyla are associated with fermentation of RS and increased SCFA production particularly butyrate. Results of experiments with humans, rats, and pigs demonstrated that benefits of dietary RS on gut health may include increased markers of mucosal barrier function, immune tolerance, and increased abundance of beneficial gut bacteria. This area of research has progressed considerably; however, its benefits during disease challenge remain unclear. Indeed, additional in vivo experiments are required to provide stronger evidence linking prebiotic effects of RS with reduced PWD and mortality. Despite the potential benefits of RS fermentation in the hindgut, utilization of SCFA resulting from RS fermentation reduces energetic efficiency compared with mostly glucose from digested starch and may thus reduce growth. To achieve a balance between increased prebiotic activity and sustained growth performance of pigs, the optimum dietary inclusion of RS, most appropriate source(s) of RS, and duration of supplementation of RS need to be determined. Nevertheless, the current state of knowledge indicates that RS as a prebiotic can enhance gut health of weaned pigs, thereby reducing the incidence of PWD. The evidence linking certain bacterial taxa and its functionality to growth and feed efficiency indicates that manipulation of gut microbiota with dietary inclusion of RS may affect pig growth performance. However, reduced PWD and especially reduced mortality following such diarrhea due to dietary RS as prebiotic is more relevant economically than dietary inclusion of RS to improve feed efficiency. Effects of feeding RS on pig performance may differ depending on the health status of pigs (healthy vs. disease challenged) and gut development, thus, different optimum levels may have to be established for each growth phase and physiological stage (e.g., growth, gestation, lactation).

\section{Abbreviations}

BCL6: B-cell lymphoma 6; C1S: Complement component 1S; CD4: Cluster of differentiation 4; CR2: Complement receptor type 2; CTSB: Cathepsin B; DEF1B: Defensin beta 1; GLP-1: Glucagon-like peptide 1; ICOS: Inducible T cell co-stimulator; IL: Interleukin; ITGB3: Integrin subunit beta 3; MCP2: Monocyte chemoattractant protein 2; MCT1: Monocarboxylate transporter 1 ;

MUC: Mucin; NFKB: Nuclear factor kappa B; PollII: RNA polymerase III; PPARY: Peroxisome proliferator-activated receptor; PWD: Post-weaning diarrhea; PYY: Peptide YY; RPS: Raw potato starch; RS: Resistant starch; SCFA: Short-chain fatty acid; SERPING1: Serpin Family G Member 1; SREBP$1 C$ : Sterol regulatory element binding protein 1c; TLR: Toll like receptor; TNFa: Tumor necrosis factor alpha

\section{Authors' contributions}

FPYT and RTZ wrote the manuscript. EB provided critical review for the content. All authors read and approved the final manuscript.

\section{Funding}

Project funding was provided by a Natural Sciences and Engineering Research Council of Canada (Ottawa, ON, Canada) Discovery Grant.

Availability of data and materials

Not applicable.

\section{Declarations}

Ethics approval and consent to participate

Not applicable.

\section{Consent for publication}

Not applicable.

\section{Competing interests}

The authors declare that they have no competing interests.

Received: 13 June 2021 Accepted: 7 October 2021

Published online: 16 November 2021

\section{References}

1. Gebhardt JT, Tokach MD, Dritz SS, DeRouchey JM, Woodworth JC, Goodband RD, et al. Postweaning mortality in commercial swine production II: Review of infectious contributing factors. Transl Anim Sci. 2020;4:485-506. https://doi.org/10.1093/tas/txaa052.

2. Fairbrother JM, Nadeau É, Gyles CL. Escherichia coli in postweaning diarrhea in pigs: an update on bacterial types, pathogenesis, and prevention strategies. Anim Heal Res Rev. 2005;6:17-39. https://doi.org/10.1079/ahr2 005105.

3. Jensen GM, Frydendahl K, Svendsen O, Jørgensen CB, Cirera S, Fredholm M et al. Experimental infection with Escherichia coli O149:F4ac in weaned piglets. Vet Microbiol. 2006;115:243-9. https://doi.org/10.1016/j.vetmic.2006. 01.002 .

4. Dong GZ, Pluske JR. The low feed intake in newly-weaned pigs: Problems and possible solutions. Asian-Australasian J Anim Sci. 2007;20:440-52. https://doi.org/10.5713/ajas.2007.440.

5. Vente-Spreeuwenberg MAM, Verdonk JMAJ, Verstegen MWA, Beynen AC, Villus height and gut development in weaned piglets receiving diets containing either glucose, lactose or starch. Br J Nutr. 2003;90:907-13. https://doi.org/10.1079/bjn2003981.

6. Vente-Spreeuwenberg MAM, Verdonk JMAJ, Bakker GCM, Beynen AC, Verstegen MWA. Effect of dietary protein source on feed intake and small intestinal morphology in newly weaned piglets. Livest Prod Sci. 2004;86: 169-77. https://doi.org/10.1016/S0301-6226(03)00166-0.

7. Spreeuwenberg MAM, Verdonk JMAJ, Gaskins HR, Verstegen MWA. Small intestine epithelial barrier function is compromised in pigs with low feed intake at weaning. J Nutr. 2001;131:1520-7. https://doi.org/10.1093/jn/131. 5.1520 .

8. Pluske JR, Turpin DL, Kim JC. Gastrointestinal tract (gut) health in the young pig. Anim Nutr. 2018;4:187-96. https://doi.org/10.1016/j.aninu.2017.12.004.

9. Wierup M. The control of microbial diseases in animals: Alternatives to the use of antibiotics. Int J Antimicrob Agents. 2000;14:315-9. https://doi.org/1 0.1016/s0924-8579(00)00143-6. 
10. Laskoski F, Tokach M, Woodworth J, Goodband R, Dritz S, DeRouchey J. Alternatives to replace the use of zinc oxide in nursery pig diets. Kansas Agric Exp Stn Res Reports. 2019;5(8). https://doi.org/10.4148/2378-5977.7838.

11. Jayaraman B, Nyachoti CM. Husbandry practices and gut health outcomes in weaned piglets: A review. Anim Nutr. 2017;3:205-11. https://doi.org/10.1 016/j.aninu.2017.06.002.

12. Rist VTS, Weiss E, Eklund M, Mosenthin R. Impact of dietary protein on microbiota composition and activity in the gastrointestinal tract of piglets in relation to gut health: A review. Animal. 2013;7:1067-78. https://doi.org/10.1 017/S1751731113000062.

13. Que JU, Casey SW, Hentges DJ. Factors responsible for increased susceptibility of mice to intestinal colonization after treatment with streptomycin. Infect Immun. 1986;53:116-23. https://doi.org/10.1128/iai. 53.1.116-123.1986

14. Williams BA, Verstegen MW, Tamminga S. Fermentation in the large intestine of single-stomached animals and its relationship to animal health. Nutr Res Rev. 2001;14:207-28. https://doi.org/10.1079/NRR200127.

15. Bhandari SK, Nyachoti CM, Krause DO. Raw potato starch in weaned pig diets and its influence on postweaning scours and the molecular microbial ecology of the digestive tract. J Anim Sci. 2009;87:984-93. https://doi.org/1 0.2527/jas.2007-0747.

16. Bird AR, Conlon MA, Christophersen CT, Topping DL. Resistant starch, large bowel fermentation and a broader perspective of prebiotics and probiotics. Benef Microbes. 2010;1:423-31. https://doi.org/10.3920/BM2010.0041.

17. Regassa A, Nyachoti CM. Application of resistant starch in swine and poultry diets with particular reference to gut health and function. Anim Nutr. 2018; 4:305-10. https://doi.org/10.1016/j.aninu.2018.04.001.

18. Sajilata M, Singhal RS, Kulkarni PR. Resistant starch-A review. Compr Rev Food Sci Food Saf. 2006;5:1-17. https://doi.org/10.1111/j.1541-4337.2006 tb00076.x.

19. Alsaffar AA. Effect of food processing on the resistant starch content of cereals and cereal products - a review. Int J Food Sci. 2011;46:455-62. https://doi.org/10.1111/j.1365-2621.2010.02529.x.

20. Evans A. Digestion resistant carbohydrates. In: Shi YC, Maningat CC, editors. Resistant Starch; 2013. https://doi.org/10.1002/9781118528723.ch05.

21. Giuberti G, Gallo A, Masoero F, Ferraretto LF, Hoffman PC, Shaver RD. Factors affecting starch utilization in large animal food production system: A review. Starch - Stärke. 2014;66:72-90. https://doi.org/10.1002/star.201300177.

22. Jane J-L, Kasemsuwan T, Leas S, Zobel H, Robyt JF. Anthology of starch granule morphology by scanning electron microscopy. Starch - Stärke. 1994; 46:121-9 https://doi.org/10.1002/star.19940460402.

23. Hizukuri S, Takeda Y, Yasuda M, Suzuki A. Multi-branched nature of amylose and the action of debranching enzymes. Carbohydr Res. 1981;94:205-13. https://doi.org/10.1016/S0008-6215(00)80718-1.

24. Copeland L, Blazek J, Salman H, Tang MC. Form and functionality of starch. Food Hydrocoll. 2009;23:1527-34. https://doi.org/10.1016/j.foodhyd.2008.09.016.

25. Buléon A, Colonna P, Planchot V, Ball S. Starch granules: Structure and biosynthesis. Int J Biol Macromol. 1998;23:85-112. https://doi.org/10.1016/ S0141-8130(98)00040-3.

26. Tester RF, Karkalas J, Qi X. Starch-composition, fine structure and architecture. J Cereal Sci. 2004;39:151-65. https://doi.org/10.1016/j.jcs.2 003.12.001.

27. Delcour J, Hoseney R. Principles of cereal science and technology. AACC Int. 2010:229-89. https://doi.org/10.1016/j.jcs.2010.01.001.

28. Sívoli L, Pérez E, Rodriguez P. Structural analysis of the cassava native starch (Manihot esculenta C.) using morphometric, chemical, thermal and rheological techniques. Rev la Fac Agron. 2012;29:293-313.

29. McPherson $A E$, Jane J. Comparison of waxy potato with other root and tuber starches. Carbohydr Polym. 1999;40:57-70. https://doi.org/10.1016/ S0144-8617(99)00039-9.

30. Jane $J \mathrm{~L}$, Chen JF. Effect of amylose molecular size and amylopectin branch chain length on paste properties of starch. Cereal Chem. 1992;69:60-5.

31. Kong B-W, Kim J-I, Kim M-J, Kim JC. Porcine pancreatic a-amylase hydrolysis of native starch granules as a function of granule surface area. Biotechnol Prog. 2003;19:1162-6. https://doi.org/10.1021/bp034005m.

32. Planchot V, Colonna P, Buleon A. Enzymatic hydrolysis of a-glucan crystallites. Carbohydr Res. 1997;298:319-26. https://doi.org/10.1016/S00086215(96)00317-5.

33. Ring SG, Gee JM, Whittam M, Orford P, Johnson IT. Resistant starch: Its chemical form in foodstuffs and effect on digestibility in vitro. Food Chem. 1988;28:97-109. https://doi.org/10.1016/0308-8146(88)90139-2.
34. Jane J-L. Structure of Starch Granules. J Appl Glycosci. 2007;54:31-6.

35. Englyst HN, Wiggins HS, Cummings JH. Determination of the non-starch polysaccharides in plant foods by gas-liquid chromatography of constituent sugars as alditol acetates. Analyst. 1982;107:307-18.

36. Englyst HN, Kingman SM, Hudson GJ, Cummings JH. Measurement of resistant starch in vitro and in vivo. Br J Nutr. 1996;75:749-55. https://doi. org/10.1079/bjn19960178.

37. Champ MMJ. Physiological aspects of resistant starch and in vivo measurements. J AOAC Int. 2004;87:749-55.

38. Giuberti G, Gallo A, Cerioli C, Masoero F. In vitro starch digestion and predicted glycemic index of cereal grains commonly utilized in pig nutrition. Anim Feed Sci Technol. 2012;174:163-73. https://doi.org/10.1016/ j.anifeedsci.2012.03.006.

39. Sun $T$, Lærke HN, Jørgensen $H$, Bach Knudsen KE. The effect ofextrusion cooking ofdifferent starch sources on the in vitro and in vivo digestibility in growing pigs. Anim. Feed Sci. Technol. 2006;131:66-85. https://doi.org/10.1 016/j.anifeedsci.2006.02.009.

40. Martinez-Puig D, Pérez JF, Castillo M, Andaluz A, Anguita M, Morales J, et al. Consumption of raw potato starch increases colon length and fecal excretion of purine bases in growing pigs. J Nutr. 2003;133:134-9. https:// doi.org/10.1093/jn/133.1.134

41. Liu Q, Donner E, Yin Y, Huang RL, Fan MZ. The physicochemical properties and in vitro digestibility of selected cereals: tubers and legumes grown in China. Food Chem. 2006;99:470-7. https://doi.org/10.1016/J.FOODCHEM.2 005.08.008.

42. Nielsen TS, Lærke HN, Theil PK, Sørensen JF, Saarinen M, Forssten S, et al. Diets high in resistant starch and arabinoxylan modulate digestion processes and SCFA pool size in the large intestine and faecal microbial composition in pigs. Br J Nutr. 2014;112:1837-49. https://doi.org/10.1017/ S000711451400302X.

43. Sun Y, Zhou L, Fang L, Su Y, Zhu W. Responses in colonic microbial community and gene expression of pigs to a long-term high resistant starch diet. Front Microbiol. 2015;6:1-10. https://doi.org/10.3389/fmicb.2015.00877.

44. Trachsel J, Briggs C, Gabler NK, Allen HK, Loving CL. Dietary resistant potato starch alters intestinal microbial communities and their metabolites, and markers of immune regulation and barrier function in swine. Front Immunol. 2019;10:1-13. https://doi.org/10.3389/fimmu.2019.01381.

45. Brown I, Warhurst M, Arcot J, Playne M, IIIman RJ, Topping DL. Fecal numbers of bifidobacteria are higher in pigs fed Bifidobacterium longum with a high amylose cornstarch than with a low amylose cornstarch. J Nutr. 1997;127:1822-7. https://doi.org/10.1093/jn/127.9.1822.

46. Topping DL, Gooden JM, Brown IL, et al. A high amylose (amylomaize) starch raises proximal large bowel starch and increases colon length in pigs. J Nutr. 1997;127:615-22. https://doi.org/10.1093/jn/127.4.615.

47. Bird AR, Vuaran M, Brown I, Topping DL. Two high-amylose maize starches with different amounts of resistant starch vary in their effects on fermentation, tissue and digesta mass accretion, and bacterial populations in the large bowel of pigs. Br J Nutr. 2007;97:134-44. https://doi.org/10.101 7/S0007114507250433.

48. Deng J, Wu X, Bin S, et al. Dietary amylose and amylopectin ratio and resistant starch content affects plasma glucose, lactic acid, hormone levels and protein synthesis in splanchnic tissues. J Anim Physiol Anim Nutr (Berl). 2010:94:220-6. https://doi.org/10.1111/j.1439-0396.2008.00902.x.

49. Regmi PR, Van Kempen TATG, Matte JJ, Zijlstra RT. Starch with high amylose and low in vitro digestibility increases short-chain fatty acid absorption, reduces peak insulin secretion, and modulates incretin secretion in pigs. J Nutr. 2011;141:398-405. https://doi.org/10.3945/jn.110.132449.

50. Woodward AD, Regmi PR, Gänzle MG, van Kempen TATG, Zijlstra RT. Slowly digestible starch influences mRNA abundance of glucose and short-chain fatty acid transporters in the porcine distal intestinal tract. J Anim Sci. 2012; 90 Suppl. 4:80-2. https://doi.org/10.2527/jas.53877.

51. Fouhse JM, Gänzle MG, Regmi PR, van Kempen TA, Zijlstra RT. High amylose starch with low in vitro digestibility stimulates hindgut fermentation and has a bifidogenic effect in weaned pigs. J Nutr. 2015;145:2464-70. https:// doi.org/10.3945/jn.115.214353.

52. Martens BMJ, Gerrits WJJ, Bruininx EMAM, Schols HA. Amylopectin structure and crystallinity explains variation in digestion kinetics of starches across botanic sources in an in vitro pig model. J Anim Sci Biotechnol. 2018;9:91. https://doi.org/10.1186/s40104-018-0303-8.

53. Van Erp RJJ, De Vries S, Van Kempen TATG, Den Hartog LA, Gerrits WJJ. Feed intake patterns nor growth rates of pigs are affected by dietary 
resistant starch, despite marked differences in digestion. Animal. 2019;14 1402-12. https://doi.org/10.1017/S1751731119002945.

54. Haenen D, Zhang J, da Silva CS, Bosch G, van der Meer IM, van Arkel J, et al. A diet high in resistant starch modulates microbiota composition, SCFA concentrations, and gene expression in pig intestine. J Nutr. 2013;143:27483. https://doi.org/10.3945/jn.112.169672.

55. Umu ÖC, Frank JA, Fangel JU, Oostindjer M, da Silva CS, Bolhuis EJ, et al. Resistant starch diet induces change in the swine microbiome and a predominance of beneficial bacterial populations. Microbiome. 2015;3:16. https://doi.org/10.1186/s40168-015-0078-5.

56. Metzler-Zebeli BU, Eberspächer E, Grüll D, Kowalczyk L, Molnar T, Zebeli Q. Enzymatically modified starch ameliorates postprandial serum triglycerides and lipid metabolome in growing pigs. PLoS One. 2015;10(6):e0130553. https://doi.org/10.1371/journal.pone.0130553.

57. Newman MA, Petri RM, Grüll D, Zebeli Q, Metzler-Zebeli BU. Transglycosylated starch modulates the gut microbiome and expression of genes related to lipid synthesis in liver and adipose tissue of pigs. Front Microbiol. 2018;9:224. https://doi.org/10.3389/fmicb.2018.00224.

58. Birkett AM, Brown IL. 4 - Resistant starch and health. In: Hamaker BR, editor. Technology of functional cereal products. Cambridge: Woodhead publishing; 2008. p. 63-85.

59. Miao M, Hamaker BR. Food matrix effects for modulating starch bioavailability. Annu Rev Food Sci Technol. 2021;12:1-23. https://doi.org/1 0.1146/annurev-food-070620-013937.

60. Seneviratne HD, Biliaderis CG. Action of a-amylases on amylose-lipid complex superstructures. J Cereal Sci. 1991;13:129-43. https://doi.org/10.101 6/S0733-5210(09)80030-1.

61. Birt D, Boylston T, Hendrich S, Jane J-L, Hollis J, Li L, et al. Resistant starch: promise for improving human health. Adv Nutr. 2013;4:587-601 https://doi. org/10.3945/an.113.004325.

62. Gutiérrez TJ, Tovar J. Update of the concept of type 5 resistant starch (RS5): Self-assembled starch V-type complexes. Trends Food Sci Technol. 2021;109: 711-24. https://doi.org/10.1016/j.tifs.2021.01.078.

63. Lærke HN, Hedemann MS. Chapter 5: The digestive system of pigs. In: Bach Knudsen KE, Kjeldsen NJ, Poulsen HD, Jensen BB, editors. Nutritional physiology of pigs - Online Publication; 2012. p. 1-27.

64. Gray GM. Starch digestion and absorption in nonruminants. J Nutr. 1992; 122:172-7.

65. Shirazi-Beechey SP, Moran AW, Batchelor DJ, Daly K, Al-Rammahi M. Glucose sensing and signalling; regulation of intestinal glucose transport. Proc Nutr Soc. 2011;70:185-93. https://doi.org/10.1017/S0029665111000103.

66. Schwartz RM, Furne JK, Levitt MD. Paracellular intestinal transport of sixcarbon sugars is negligible in the rat. Gastroenterology. 1995;109:1206-13. https://doi.org/10.1016/0016-5085(95)90580-4.

67. Wijtten PJ, van der Meulen J, Verstegen MW. Intestinal barrier function and absorption in pigs after weaning: a review. Br J Nutr. 2011;105:967-81. https://doi.org/10.1017/S0007114510005660.

68. Affleck JA, Helliwell PA, Kellett GL. Immunocytochemical detection of GLUT2 at the rat intestinal brush-border membrane. J Histochem Cytochem. 2003; 51:1567-74. https://doi.org/10.1177/002215540305101116.

69. Chaudhry RM, Scow JS, Madhavan S, Duenes JA, Sarr MG. Acute enterocyte adaptation to luminal glucose: a posttranslational mechanism for rapid apical recruitment of the transporter GLUT2. J Gastrointest Surg. 2012;16: 312-9. https://doi.org/10.1007/s11605-011-1752-y.

70. Röder PV, Geillinger KE, Zietek TS, Thorens B, Koepsell H, Daniel H. The role of SGLT1 and GLUT2 in intestinal glucose transport and sensing. PLOS One. 2014;9(2):e89977. https://doi.org/10.1371/journal.pone.0089977.

71. Chen $L$, Tuo B, Dong H. Regulation of intestinal glucose absorption by ion channels and transporters. Nutrients. 2016;8(1):43. https://doi.org/10.3390/ nu8010043.

72. Englyst HN, Kingman SM, Cummings JH. Classification and measurement of nutritionally important starch fractions. Eur J Clin Nutr. 1992;46 Suppl 2:S33-50.

73. den Besten G, van Eunen K, Groen AK, Venema K, Reijngoud D, Bakker BM. The role of short-chain fatty acids in the interplay between diet, gut microbiota, and host energy metabolism. J Lipid Res. 2013;54:2325-40.

74. Sepponen K, Ruusunen M, Pakkanen JA, Pösö AR. Expression of CD147 and monocarboxylate transporters MCT1, MCT2 and MCT4 in porcine small intestine and colon. Vet J. 2007;174:122-8.

75. Bach Knudsen KE, Lærke HN, Steenfeldt S, Hedemann MS, Jørgensen H. In vivo methods to study the digestion of starch in pigs and poultry. Anim Feed Sci Technol. 2006;130:114-35.
76. Zijlstra RT, Jha R, Woodward AD, Fouhse J, van Kempen TATG. Starch and fiber properties affect their kinetics of digestion and thereby digestive physiology in pigs. J Anim Sci. 2012;90:49-58.

77. Hooda S, Matte JJ, Wilkinson CW, Zijlstra RT. Technical note: An improved surgical model for the long-term studies of kinetics and quantification of nutrient absorption in swine. J Anim Sci. 2009;87:2013-9.

78. Li TJ, Dai QZ, Yin YL, Zhang J, Huang RL, Ruan Z, et al. Dietary starch sources affect net portal appearance of amino acids and glucose in growing pigs. Animal. 2008;2(5):723-9. https://doi.org/10.1017/S1751731108001614.

79. Payne JA, King EW, Beinhart G. Arthropod succession and decomposition of buried pigs. Nature. 1968;219:1180-1.

80. Vasanthan T, Hoover R. A comparative study of the composition of lipids associated with starch granules from various botanical sources. Food Chem. 1992;43:19-27.

81. Dhital S, Bhattarai RR, Gorham J, Gidley MJ. Intactness of cell wall structure controls the in vitro digestion of starch in legumes. Food Funct. 2016;7: 1367-79. https://doi.org/10.1039/c5fo01104c.

82. Zhou X, Ying Y, Hu B, Pang Y, Bao J. Physicochemical properties and digestibility of endosperm starches in four indica rice mutants. Carbohydr Polym. 2018;195:1-8. https://doi.org/10.1016/j.carbpol.2018.04.070.

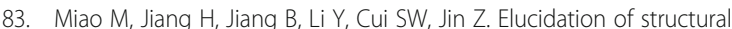
difference in theaflavins for modulation of starch digestion. J Funct Foods 2013;5:2024-9. https://doi.org/10.1016/j.jf.2013.09.021.

84. Zhu F. Interactions between starch and phenolic compound. Trends Food Sci Technol. 2015;43:129-43. https://doi.org/10.1016/j.tifs.2015.02.003.

85. Dartois $A$, Singh J, Kaur L, Singh $H$. Influence of guar gum on the in vitro starch digestibility-Rheological and microstructural characteristics. Food Biophys. 2010;5:149-60. https://doi.org/10.1007/s11483-010-9155-2.

86. Zhang J, Luo K, Zhang G. Impact of native form oat $\beta$-glucan on starch digestion and postprandial glycemia. J Cereal Sci. 2017;73:84-90. https://doi. org/10.1016/j.jcs.2016.11.013.

87. Gaskins HR, Collier CT, Anderson DB. Antibiotics as growth promotants: mode of action. Anim Biotechnol. 2002;13:29-42. https://doi.org/10.1081/A BIO-120005768.

88. Allison MJ, Robinson IM, Bucklin JA, Booth GD. Comparison of bacterial populations of the pig cecum and colon based upon enumeration with specific energy sources. Appl Environ Microbiol. 1979;37:1142-51.

89. Russell EG. Types and distribution of anaerobic bacteria in the large intestine of pigs. Appl Environ Microbiol. 1979;37:187-93.

90. Leser TD, Amenuvor JZ, Jensen TK, Lindecrona RH, Boye M, Moøller K. Culture-independent analysis of gut bacteria: The pig gastrointestinal tract microbiota revisited. Appl Environ Microbiol. 2002;68:673-90. https://doi. org/10.1128/AEM.68.2.673-690.2002

91. Isaacson R, Kim HB. The intestinal microbiome of the pig. Anim Health Res Rev. 2012;13:100-9. https://doi.org/10.1017/S1466252312000084.

92. Adhikari B, Kim SW, Kwon YM. Characterization of microbiota associated with digesta and mucosa in different regions of gastrointestinal tract of nursery pigs. Int J Mol Sci. 2019;20:9-12. https://doi.org/10.3390/ijms20071630.

93. Regmi PR, Metzler-Zebeli BU, Gänzle MG, van Kempen TATG, Zijlstra RT. Starch with high amylose content and low in vitro digestibility increases intestinal nutrient flow and microbial fermentation and selectively promotes bifidobacteria in pigs. J Nutr. 2011;141:1273-80. https://doi.org/10.3945/ in.111.140509.

94. Nagy B, Fekete PZ. Enterotoxigenic Escherichia coli in veterinary medicine. Int J Med Microbiol. 2005;295:443-54. https://doi.org/10.1016/j.jimm.2005.07.003.

95. Benson AK, Kelly SA, Legge R, Ma F, Low SJ, Kim J, et al. Individuality in gut microbiota composition is a complex polygenic trait shaped by multiple environmental and host genetic factors. Proc Natl Acad Sci. 2010;107: 18933-8. https://doi.org/10.1073/pnas.1007028107.

96. Sharon I, Morowitz MJ, Thomas BC, Costello EK, Relman DA, Banfield JF. Time series community genomics analysis reveals rapid shifts in bacterial species, strains, and phage during infant gut colonization. Genome Res. 2013;23:111-20. https://doi.org/10.1101/gr.142315.112.

97. Frese SA, Parker K, Calvert CC, Mills DA. Diet shapes the gut microbiome of pigs during nursing and weaning. Microbiome. 2015;3:28. https://doi.org/1 0.1186/s40168-015-0091-8

98. Wang W, Hu H, Zijlstra RT, Zheng J, Gänzle MG. Metagenomic reconstructions of gut microbial metabolism in weanling pigs. Microbiome. 2019;7:1-11. https://doi.org/10.1186/s40168-019-0662-1.

99. Metzler-Zebeli BU, Canibe N, Montagne L, Freire J, Bosi P, Prates JAM, et al. Resistant starch reduces large intestinal $\mathrm{pH}$ and promotes fecal lactobacilli 
and bifidobacteria in pigs. Animal. 2019;13(1):64-73. https://doi.org/10.1017/ S1751731118001003.

100. Leblois J, Massart S, Soyeurt H, Grelet C, Dehareng F, Schroyen M, et al. Feeding sows resistant starch during gestation and lactation impacts their faecal microbiota and milk composition but shows limited effects on their progeny. PLoS One. 2018;13:e0199568. https://doi.org/10.1371/journal.pone. 0199568.

101. Topping DL, Clifton PM. Short-chain fatty acids and human colonic function: Roles of resistant starch and nonstarch polysaccharides. Physiol Rev. 2001; 81:1031-64. https://doi.org/10.1152/physrev.2001.81.3.1031.

102. Gardiner GE, Metzler-Zebeli BU, Lawlor PG. Impact of Intestinal Microbiota on Growth and Feed Efficiency in Pigs: A review. Microorganisms. 2020; 8(12):1886. https://doi.org/10.3390/microorganisms8121886.

103. Macfarlane GT, Macfarlane S. Human colonic microbiota: Ecology, physiology and metabolic potential of intestinal bacteria. Scand J Gastroenterol Suppl. 1997;32:3-9. https://doi.org/10.1080/00365521.1997.11720708

104. Roediger WE. Utilization of nutrients by isolated epithelial cells of the rat colon. Gastroenterology. 1982;83:424-9.

105. Hamer HM, Jonkers D, Venema K, Vanhoutvin S, Troost FJ, Brummer R-J. Review article: the role of butyrate on colonic function. Aliment Pharmacol Ther. 2008;27:104-19. https://doi.org/10.1111/j.1365-2036.2007.03562.x.

106. Macfarlane GT, Gibson GR, Beatty E, Cummings JH. Estimation of short-chain fatty acid production from protein by human intestinal bacteria based on branched-chain fatty acid measurements. FEMS Microbiol Lett. 1992;101:81-8.

107. Bach Knudsen KE, Jensen BB, Andersen JO, Hansen I. Gastrointestinal implications in pigs of wheat and oat fractions. 2. Microbial activity in the gastrointestinal tract. Br J Nutr. 1991;65:233-48.

108. Jensen BB, Jørgensen $\mathrm{H}$. Effect of dietary fiber on microbial activity and microbial gas production in various regions of the gastrointestinal tract of pigs. Appl Environ Microbiol. 1994;60:1897-904.

109. Cummings JH, Macfarlane GT. The control and consequences of bacterial fermentation in the human colon. J Appl Bacteriol. 1991;70:443-59.

110. Nielsen TS, Theil PK, Purup S, Nørskov NP, Bach Knudsen KE. Effects of resistant starch and arabinoxylan on parameters related to large intestinal and metabolic health in pigs fed fat-rich diets. J Agric Food Chem. 2015;63: 10418-30. https://doi.org/10.1021/acs.jafc.5b03372.

111. Hampson DJ, Kidder DE. Influence of creep feeding and weaning on brush border enzyme activities in the piglet small intestine. Res Vet Sci. 1986;40:24-31.

112. Pluske JR, Hampson DJ, Williams IH. Factors influencing the structure and function of the small intestine in the weaned pig: A review. Livest Prod Sci. 1997;51:215-36. https://doi.org/10.1016/50301-6226(97)00057-2.

113. Dai Z, Wu Z, Hang S, Zhu W, Wu G. Amino acid metabolism in intestinal bacteria and its potential implications for mammalian reproduction. Mol Hum Reprod. 2014;21:389-409. https://doi.org/10.1093/molehr/gav003.

114. Dai Z-L, Zhang J, Wu G, Zhu W-Y. Utilization of amino acids by bacteria from the pig small intestine. Amino Acids. 2010;39:1201-15. https://doi. org/10.1007/s00726-010-0556-9.

115. Derrien M, Collado MC, Ben-Amor K, Salminen S, de Vos WM. The mucin degrader Akkermansia muciniphila is an abundant resident of the human intestinal tract. Appl Environ Microbiol. 2008;74:1646-8. https://doi.org/1 0.1128/AEM.01226-07.

116. Smith EA, Macfarlane GT. Enumeration of amino acid fermenting bacteria in the human large intestine: effects of $\mathrm{pH}$ and starch on peptide metabolism and dissimilation of amino acids. FEMS Microbiol Ecol. 1998;25:355-68.

117. Libao-Mercado AJO, Zhu CL, Cant JP, Lapierre H, Thibault J-N, Sève B, et al. Dietary and endogenous amino acids are the main contributors to microbial protein in the upper gut of normally nourished pigs. J Nutr. 2009; 139:1088-94. https://doi.org/10.3945/jn.108.103267.

118. Bikker P, Dirkzwager A, Fledderus J, Trevisi P, le Huërou-Luron I, Lallès JP, et al. The effect of dietary protein and fermentable carbohydrates levels on growth performance and intestinal characteristics in newly weaned piglets. J Anim Sci. 2006;84:3337-45. https://doi.org/10.2527/jas.2006-076.

119. Cherrington CA, Hinton M, Pearson GR, Chopra I. Short-chain organic acids at pH 5.0 kill Escherichia coli and Salmonella spp. without causing membrane perturbation. J Appl Bacteriol. 1991;70:161-5.

120. Duncan SH, Louis $\mathrm{P}$, Thomson JM, Flint HJ. The role of $\mathrm{pH}$ in determining the species composition of the human colonic microbiota. Environ Microbiol. 2009;11:2112-22. https://doi.org/10.1111/j.1462-2920.2009.01931.x.

121. Cummings JH, Pomare EW, Branch HWJ, Naylor CPE, MacFarlane GT. Short chain fatty acids in human large intestine, portal, hepatic and venous blood Gut. 1987;28:1221-7.
122. Duncan SH, Scott KP, Ramsay AG, Harmsen HJM, Welling GW, Stewart CS, et al. Effects of alternative dietary substrates on competition between human colonic bacteria in an anaerobic fermentor system. Appl Environ Microbiol. 2003;69:1136-42. https://doi.org/10.1128/AEM.69.2.1136-1142.2 003.

123. Walker AW, Duncan SH, McWilliam Leitch EC, Child MW, Flint HJ. pH and peptide supply can radically alter bacterial populations and short-chain fatty acid ratios within microbial communities from the human colon. Appl Environ Microbiol. 2005;71:3692-700. https://doi.org/10.1128/AEM.71.7.3 692-3700.2005.

124. Moeser AJ, Pohl CS, Rajput M. Weaning stress and gastrointestinal barrier development: Implications for lifelong gut health in pigs. Anim Nutr. 2017;3: 313-21. https://doi.org/10.1016/j.aninu.2017.06.003.

125. Humphrey B, Zhao J, Faris R. Review: Link between intestinal immunity and practical approaches to swine nutrition. Animal. 2019;13:2736-44 https://doi. org/10.1017/S1751731119001861.

126. Moeser AJ, Blikslager AT. Mechanisms of porcine diarrheal disease. J Am Vet Med Assoc. 2007;231:56-67. https://doi.org/10.2460/javma.231.1.56.

127. Haenen D, da Silva CS, Zhang J, Koopmans SJ, Bosch G, Vervoort J, et al. Resistant starch induces catabolic but suppresses immune and cell division pathways and changes the microbiome in the proximal colon of male pigs. J Nutr. 2013;143:1889-98. https://doi.org/10.3945/jn.113.182154.

128. Zhou L, Fang L, Sun Y, Su Y, Zhu W. Effects of a diet high in resistant starch on fermentation end-products of protein and mucin secretion in the colons of pigs. Starch - Stärke. 2017;69:1600032. https://doi.org/10.1002/star.201 600032.

129. Ren W, Yan H, Yu B, Walsh MC, Yu J, Zheng P, et al. Prevotella-rich enterotype may benefit gut health in finishing pigs fed a diet with high amylose-to-amylopectin ratio. Anim Nutr. 2021;7:400-11. https://doi.org/10.1 016/j.aninu.2020.08.007.

130. Qin S, Zhang K, Applegate TJ, Ding X, Bai S, Luo Y, et al. Dietary administration of resistant starch improved caecal barrier function by enhancing intestinal morphology and modulating microbiota composition in meat duck. Br J Nutr. 2020;123:172-81. https://doi.org/10.1017/S0007114 519002319

131. Peng L, Li Z-R, Green RS, Holzman IR, Lin J. Butyrate enhances the intestinal barrier by facilitating tight junction assembly via activation of AMP-activated protein kinase in Caco-2 cell monolayers. J Nutr. 2009;139:1619-25. https:// doi.org/10.3945/jn.109.104638.

132. Leonel AJ, Alvarez-Leite Jl. Butyrate: implications for intestinal function. Curr Opin Clin Nutr Metab Care. 2012;15:474-9. https://doi.org/10.1097/MCO. Ob013e32835665fa.

133. Arpaia N, Rudensky AY. Microbial metabolites control gut inflammatory responses. Proc Natl Acad Sci. 2014;111(6):2058-9. https://doi.org/10.1073/ pnas.1323183111.

134. Park J, Kim M, Kang SG, Jannasch AH, Cooper B, Patterson J, et al. Shortchain fatty acids induce both effector and regulatory $T$ cells by suppression of histone deacetylases and regulation of the mTOR-S6K pathway. Mucosal Immunol. 2015;8:80-93. https://doi.org/10.1038/mi.2014.44.

135. Hoeppli RE, Wu D, Cook L, Levings MK. The environment of regulatory T cell biology: Cytokines, metabolites, and the microbiome. Front Immunol. 2015; 6:1-14. https://doi.org/10.3389/fimmu.2015.00061.

136. Bhaskaran N, Quigley C, Paw C, Butala S, Schneider E, Pandiyan P. Role of short chain fatty acids in controlling $T$ (regs) and immunopathology during mucosal infection. Front Microbiol. 2018;9:1995. https://doi.org/10.3389/ fmicb.2018.01995.

137. Yang W, Yu T, Huang X, Bilotta AJ, Yao S, Cong Y. Short chain fatty acids regulate T cell metabolism to promote IL-22 production and gut immunity. J Immunol. 2020:204:83.4 LP-83.4.

138. Arpaia N, Campbell C, Fan X, Dikiy S, van der Veeken J, de Roos P, et al. Metabolites produced by commensal bacteria promote peripheral regulatory T-cell generation. Nature. 2013;504:451-5. https://doi.org/10.1038/ nature12726.

139. Chang PV, Hao L, Offermanns S, Medzhitov R. The microbial metabolite butyrate regulates intestinal macrophage function via histone deacetylase inhibition. Proc Natl Acad Sci. 2014;111(6):2247-52. https://doi.org/10.1073/ pnas.1322269111.

140. Schley PD, Field CJ. The immune-enhancing effects of dietary fibres and prebiotics. Br J Nutr. 2002;87:S221-30. https://doi.org/10.1079/BJNBJN/2002541.

141. Villodre Tudela C, Boudry C, Stumpff F, Aschenbach JR, Vahjen W, Zentek J, et al. Down-regulation of monocarboxylate transporter 1 (MCT1) gene 
expression in the colon of piglets is linked to bacterial protein fermentation and pro-inflammatory cytokine-mediated signalling. Br J Nutr. 2015;113:6107. https://doi.org/10.1017/S0007114514004231.

142. Wiseman J. Variations in starch digestibility in non-ruminants. Anim Feed Sci Technol. 2006;130:66-77. https://doi.org/10.1016/j.anifeedsci.2006.01.018.

143. Rosenfelder-Kuon P, Strang EJP, Spindler HK, Eklund M, Mosenthin R. lleal starch digestibility of different cereal grains fed to growing pigs. J Anim Sci. 2017;95:2711-7. https://doi.org/10.2527/jas.2017.1450.

144. Van Der Meulen J, Bakker JGM, Smits B, De Visser H. Effect of source of starch on net portal flux of glucose, lactate, volatile fatty acids and amino acids in the pig. Br J Nutr. 1997;78:533-44. https://doi.org/10.1079/bjn1 9970173.

145. Van Der Meulen J, Bakker GCM, Bakker JGM, De Visser H, Jongbloed AW, Everts $\mathrm{H}$. Effect of resistant starch on net portal-drained viscera flux of glucose, volatile fatty acids, urea, and ammonia in growing pigs. J Anim Sci. 1997;75:2697-704. https://doi.org/10.2527/1997.75102697x.

146. van Kempen TATG, Regmi PR, Matte JJ, ZijIstra RT. In vitro starch digestion kinetics, corrected for estimated gastric emptying, predict portal glucose appearance in pigs. J Nutr. 2010;140:1227-33. https://doi.org/10.3945/jn.1 09.120584 .

147. Baggio LL, Drucker DJ. Biology of incretins: GLP-1 and GIP. Gastroenterology. 2007;132:2131-57. https://doi.org/10.1053/j.gastro.2007.03.054.

148. Kim W, Egan JM. The role of incretins in glucose homeostasis and diabetes treatment. Pharmacol Rev. 2008;60:470-512.

149. Shirazi-Beechey SP, Moran AW, Bravo D, Al-Rammahi M. Nonruminant nutrition symposium: Intestinal glucose sensing and regulation of glucose absorption: Implications for swine nutrition. J Anim Sci. 2011;89:1854-62. https://doi.org/10.2527/jas.2010-3695.

150. Nelson G, Hoon MA, Chandrashekar J, Zhang Y, Ryba NJ, Zuker CS. Mammalian sweet taste receptors. Cell. 2001;106:381-90. https://doi.org/10.1 016/s0092-8674(01)00451-2.

151. Moran AW, Al-Rammahi MA, Arora DK, Batchelor DJ, Coulter EA, Daly K, et al. Expression of $\mathrm{Na}+$ /glucose co-transporter 1 (SGLT1) is enhanced by supplementation of the diet of weaning piglets with artificial sweeteners. Br J Nutr. 2010;104:637-46. https://doi.org/10.1017/50007114510000917.

152. Montague W, Taylor KW. Regulation of insulin secretion by short chain fatty acids. Nature. 1968;217:853.

153. Brown AJ, Goldsworthy SM, Barnes AA, Eilert MM, Tcheang L, Daniels D, et al. The Orphan G protein-coupled receptors GPR41 and GPR43 are activated by propionate and other short chain carboxylic acids. J Biol Chem. 2003;278:11312-9. https://doi.org/10.1074/jbc.M211609200.

154. Stoddart LA, Smith NJ, Milligan G. International Union of Pharmacology. LXXI. Free fatty acid receptors FFA1, -2 , and -3 : pharmacology and pathophysiological functions. Pharmacol Rev. 2008;60(4):405-17. https://doi. org/10.1124/pr.108.00802.

155. Hirasawa A, Tsumaya K, Awaji T, Katsuma S, Adachi T, Yamada M, et al. Free fatty acids regulate gut incretin glucagon-like peptide-1 secretion through GPR120. Nat Med. 2005;11:90-4. https://doi.org/10.1038/nm1168.

156. Friedlander RS, Moss CE, Mace J, Parker HE, Tolhurst G, Habib AM, et al. Role of phosphodiesterase and adenylate cyclase isozymes in murine colonic glucagon-like peptide 1 secreting cells. Br J Pharmacol. 2011;163:261-71. https://doi.org/10.1111/j.1476-5381.2010.01107.x.

157. Batterham RL, Cowley MA, Small CJ, Herzog H, Cohen MA, Dakin CL, et al. Gut hormone PYY (3-36) physiologically inhibits food intake. Nature. 2002; 418:650-4. https://doi.org/10.1038/nature00887.

158. van den Hoek AM, Heijboer AC, Corssmit EPM, Voshol PJ, Romijn JA, Havekes LM, et al. PYY3-36 reinforces insulin action on glucose disposal in mice fed a high-fat diet. Diabetes. 2004;53:1949-52. https://doi.org/10.2337/ diabetes.53.8.1949.

159. Boey D, Lin S, Karl T, Baldock P, Lee N, Enriquez R, et al. Peptide YY ablation in mice leads to the development of hyperinsulinaemia and obesity. Diabetologia. 2006;49:1360-70. https://doi.org/10.1007/s00125-006-0237-0.

160. Kaji I, Karaki S-I, Tanaka R, Kuwahara A. Density distribution of free fatty acid receptor 2 (FFA2)-expressing and GLP-1-producing enteroendocrine $L$ cells in human and rat lower intestine, and increased cell numbers after ingestion of fructo-oligosaccharide. J Mol Histol. 2011;42:27-38. https://doi. org/10.1007/s10735-010-9304-4.

161. Tolhurst G, Heffron H, Lam YS, Parker HE, Habib AM, Diakogiannaki E, et al, Short-chain fatty acids stimulate glucagon-like peptide-1 secretion via the G-protein-coupled receptor FFAR2. Diabetes. 2012;61:364-71. https://doi. org/10.2337/db11-1019.
162. Zhang J-M, Sun Y-S, Zhao L-Q, Chen T-T, Fan M-N, Jiao H-C, et al. SCFAsinduced GLP-1 secretion links the regulation of gut microbiome on hepatic lipogenesis in chickens. Front Microbiol. 2019;10:2176. https://doi.org/10.33 89/fmicb.2019.02176.

163. Higgins JA, Higbee DR, Donahoo WT, Brown IL, Bell ML, Bessesen DH. Resistant starch consumption promotes lipid oxidation. Nutr Metab. 2004;1: 8. https://doi.org/10.1186/1743-7075-1-8.

164. Dunshea FR. Effect of metabolism modifiers on lipid metabolism in the pig. J Anim Sci. 1993;71:1966-77.

165. Louveau I, Gondret F. Regulation of development and metabolism of adipose tissue by growth hormone and the insulin-like growth factor system. Domest Anim Endocrinol. 2004;27:241-55. https://doi.org/10.1016/j. domaniend.2004.06.004

166. Yin F, Yin Y, Zhang Z, Xie M, Huang J, Huang R, et al. Digestion rate of dietary starch affects the systemic circulation of lipid profiles and lipid metabolism-related gene expression in weaned pigs. Br J Nutr. 2011;106: 369-77. https://doi.org/10.1017/S0007114511000213.

167. He J, Chen D, Zhang K, Yu B. A high-amylopectin diet caused hepatic steatosis associated with more lipogenic enzymes and increased serum insulin concentration. Br J Nutr. 2011;106:1470-5. https://doi.org/10.1017/ S0007114511001966.

168. Jiao AR, Diao H, Yu B, He J, Yu J, Zheng P, et al. Oral administration of short chain fatty acids could attenuate fat deposition of pigs. PLoS One. 2018;13: 1-12. https://doi.org/10.1371/journal.pone.0196867.

169. Xie C, Li Y, Li J, Zhang L, Zhou G, Gao F. Dietary starch types affect liver nutrient metabolism of finishing pigs. Br J Nutr. 2017;118(5)353-9. https:// doi.org/10.1017/S0007114517002252.

170. Jørgensen $H$, Larsen $T$, Zhao XQ, Eggum BO. The energy value of shortchain fatty acids infused into the caecum of pigs. Br J Nutr. 1997;77:745-56. https://doi.org/10.1079/bjn19970072.

171. Noblet J, van Milgen J. Energy value of pig feeds: effect of pig body weight and energy evaluation system. J Anim Sci. 2004;82(suppl_13):E229-38. https://doi.org/10.2527/2004.8213_supplE229x .

172. Gerrits WJJ, Bosch MW, van den Borne JJGC. Quantifying resistant starch using novel, in vivo methodology and the energetic utilization of fermented starch in pigs. J Nutr. 2012;142:238-44. https://doi.org/10.3945/ jn.111.147496

173. Fouhse JM, Zijlstra RT. Impact of resistant vs. digested starch on starch energy value in the pig gut. Bioact Carbohydrates Diet Fibre. 2018;15:12-20. https://doi.org/10.1016/j.bcdf.2017.08.001.

174. Noblet J, Fortune H, Shi XS, Dubois S. Prediction of net energy value of feeds for growing pigs. J Anim Sci. 1994;72:344-54

175. National Research Council. Nutrient Requirements of Swine. 11th ed. Washington: The National Academies Press; 2012.

176. Schrama JW, Bakker GC. Changes in energy metabolism in relation to physical activity due to fermentable carbohydrates in group-housed growing pigs. J Anim Sci. 1999;77:3274-80. https://doi.org/10.2527/1999.77123274x.

177. Bolhuis JE, van den Brand H, Staals STM, Zandstra T, Alferink SJJ, Heetkamp MJW, et al. Effects of fermentable starch and straw-enriched housing on energy partitioning of growing pigs. Animal. 2008;2:1028-36. https://doi. org/10.1017/S175173110800222X.

178. de Leeuw JA, Bolhuis JE, Bosch G, Gerrits WJJ. Effects of dietary fibre on behaviour and satiety in pigs. Proc Nutr Soc. 2008;67:334-42. https://doi. org/10.1017/S002966510800863X.

179. da Silva CS, van den Borne JJGC, Gerrits WJJ, Kemp B, Bolhuis JE. Effects of dietary fibers with different physicochemical properties on feeding motivation in adult female pigs. Physiol Behav. 2012;107:218-30. https://doi. org/10.1016/j.physbeh.2012.07.001.

180. Black JL, Williams BA, Gidley MJ. Metabolic regulation of feed intake in monogastric mammals. In: Torrallardona D, Roura E, editors. Volunt feed intake pigs. Wageningen: Academic; 2009. p. 187-211.

181. Nyachoti CM, Zijlstra RT, de Lange CFM, Patience JF. Voluntary feed intake in growing-finishing pigs: A review of the main determining factors and potential approaches for accurate predictions. Can J Anim Sci. 2004;84:54966. https://doi.org/10.4141/A04-001.

182. Ratanpaul V, Williams BA, Black JL, Gidley MJ. Review: Effects of fibre, grain starch digestion rate and the ileal brake on voluntary feed intake in pigs. Animal. 2019;13:2745-54. https://doi.org/10.1017/S175173111 9001459.

183. de Leeuw JA, Jongbloed AW, Spoolder HAM, Verstegen MWA. Effects of hindgut fermentation of non-starch polysaccharides on the stability of 
blood glucose and insulin levels and physical activity in empty sows. Livest Prod Sci. 2005;96:165-74. https://doi.org/10.1016/j.livprodsci.2005.01.009.

184. Sleeth M, Thompson E, Ford H, Zac-Varghese S, Frost G. Free fatty acid receptor 2 and nutrient sensing: A proposed role for fibre, fermentable carbohydrates and short-chain fatty acids in appetite regulation. Nutr Res Rev. 2010;23:135-45. https://doi.org/10.1017/S0954422410000089.

185. Maljaars P, Peters H, Mela DJ, Masclee AAM. Ileal brake: A sensible food target for appetite control. A review. Physiol Behav. 2008;95:271-81. https:// doi.org/10.1016/j.physbeh.2008.07.018.

186. Chambers ES, Morrison DJ, Frost G. Control of appetite and energy intake by SCFA: What are the potential underlying mechanisms? Proc Nutr Soc. 2015;74:328-36. https://doi.org/10.1017/S0029665114001657.

187. Van Kempen TATG, Zijlstra RT. 2015. The impact of glycemic index in diets and its utilization in feed formulation for optimal performance. Montreal, QC, Canada: Proc. 51st East. Nutr. Conf: pp. 129-136.

188. Li TJ, Huang RL, Wu GY, Lin YC, Jiang ZY, Kong XF, et al. Growth performance and nitrogen metabolism in weaned pigs fed diets containing different sources of starch. Livest Sci. 2007;109:73-6. https://doi.org/10.1016/ j.livsci.2007.01.073.

189. Yang C, Chen D, Yu B, Huang Z, Mao X, Yu J, et al. Effect of dietary amylose/amylopectin ratio on growth performance, carcass traits, and meat quality in finishing pigs. Meat Sci. 2015;108:55-60. https://doi.org/10.1016/j. meatsci.2015.05.026.

190. Doti S, Suarez Belloch J, Latorre Gorriz M, Guada JA, Fondevila M. Effect of dietary starch source on growth performances, digestibility and quality traits of growing pigs. Livest Sci. 2014;164:119-27. https://doi.org/10.1016/j.livsci.2 014.03.016.

191. van Erp RJJ, van Hees HMJ, Zijlstra RT, van Kempen TATG, van Klinken JB, Gerrits WJJ. Reduced feed intake, rather than increased energy losses, explains variation in growth rates of normal-birth-weight piglets. J Nutr. 2018;148:1794-803. https://doi.org/10.1093/jn/nxy200.

192. Silva CS, Haenen D, Koopmans SJ, Hooiveld GJEJ, Bosch G, Bolhuis JE, et al. Effects of resistant starch on behaviour, satiety-related hormones and metabolites in growing pigs. Anim. 2014;8(9):1402-11. https://doi.org/10.101 7/S1751731114001116.

193. Ingerslev AK, Mutt SJ, Lærke HN, Hedemann MS, Theil PK, Nielsen KL, et al. Postprandial PYY increase by resistant starch supplementation is independent of net portal appearance of short-chain fatty acids in pigs. PLoS One. 2017;12:1-16. https://doi.org/10.1371/journal.pone.0185927.

Ready to submit your research? Choose BMC and benefit from:

- fast, convenient online submission

- thorough peer review by experienced researchers in your field

- rapid publication on acceptance

- support for research data, including large and complex data types

- gold Open Access which fosters wider collaboration and increased citations

- maximum visibility for your research: over $100 \mathrm{M}$ website views per year

At $\mathrm{BMC}$, research is always in progress.

Learn more biomedcentral.com/submissions 